\author{
ANTONIO RUBIAL GARCÍA \\ FACULTAD DE FILOSOFÍA Y LETRAS, UNAM
}

\title{
Hortus eremitarum \\ Las pinturas de tebaidas en los claustros agustinos
}

Son más santos aquellos religiosos que apartados de los hombres conversan con los ángeles.

San Agustín

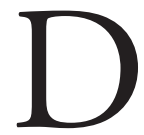

ESDE QUE FUNDARON SU ORDEN mendicante en I256, los agustinos consideraron que la vida eremítica sería su carácter más distintivo. El mismo nombre que tomaron, "ermitaños de San Agustín”, marcaba la vocación por la vida retirada, aunque muy pronto sus actividades en las ciudades los obligaron a convertir ese ideario en un mero recurso retórico. Sin embargo, el tema del eremitismo fue un tópico recurrente en los escritos y en la iconografía de esta congregación religiosa a lo largo de los siglos. De hecho el eremitismo fue la piedra de toque en las reformas que la orden sufrió a lo largo de los siglos XIV Y Xv, durante los cuales el retiro del mundo se asimilaba a la observancia, mientras que la actividad erudita y universitaria se relacionaba con los conventuales y la relajación.

En la península ibérica los observantes tenían en poca estima los estudios pues, con el pretexto de ellos, se habían introducido en la orden algunos excesos en la concesión de privilegios para quienes poseían grados. Además, el espíritu eremítico de la orden que ellos profesaban tenía como ideario la exaltación de la simplicidad y, por tanto, compartían con los místicos los ataques contra lo que llamaban "la vanidad" de los escolásticos. Los conventuales, por su parte, consideraban que los estudios eran un elemento fundamental del espíritu de su patrono san Agustín. A lo largo del siglo xv, los observantes absorbieron poco 
a poco a los conventuales hasta llegar a la unión de ambas ramas en el capítulo de Toledo de 1504. Después de éste, sin embargo, se insistió en la importancia de los estudios que promovían los conventuales, aunque se conservó el ideal eremítico como un símbolo del espíritu original con que se fundó la orden. ${ }^{\mathrm{I}}$

Cuando los agustinos llegaron a la Nueva España en I533, reprodujeron en estas tierras ambas tendencias: la de carácter eremítico, representada por hombres como fray Juan Bautista Moya y fray Antonio de Roa, y la que insistía en promover los estudios, que tuvo su mayor defensor en fray Alonso de la Veracruz, uno de los fundadores de la Universidad de México y de varios colegios en la orden. Ambas tendencias, sin embargo, resultaron afectadas por una peculiaridad del territorio novohispano: en él era muy difícil compaginar la vida contemplativa del ermitaño o del estudioso con la actividad misionera. ${ }^{2}$ Fray Juan de Grijalva remontaba esta confrontación entre los partidarios de la vida activa y los de la contemplativa a los orígenes mismos de la orden: "las mismas dificultades tuvo antiguamente nuestra religión para salir de las soledades al poblado, pareciéndoles que por el bien de otros no debían arriesgar el propio". ${ }^{3}$

Por ello, en los primeros años de actividad de los misioneros agustinos terminó por imponerse la vida activa, aunque el gusto por las soledades produjo continuos brotes eremíticos entre ellos, al mismo tiempo que se volvía un tópico literario de sus cronistas hasta bien entrado el siglo XvıII. ${ }^{4}$ En fray Juan de Grijalva, por ejemplo, la anacoresis individual se mencionó constantemente al hablar de los misioneros que se lanzaban a la evangelización de los indios de las sierras. Los agustinos se encargaron de misionar en territorios con una población muy dispersa, lo que les daba, según el cronista, las posibilidades de pasar solitarios largas temporadas. Así, tanto fray Antonio de Roa, evangelizador de la Sierra Alta, como fray Juan Bautista Moya, el apóstol de la tierra caliente de Michoacán, fueron considerados anacoretas por su biógrafo. Las solitarias regiones que

I. Luis Álvarez Gutiérrez, El movimiento observante agustiniano en España y su culminación en tiempo de los Reyes Católicos, Roma, Analecta Augustiniana (Studia Augustiniana Historica, 6), 1978 .

2. Sobre el eremitismo en Nueva España véase mi artículo "Tebaidas en el paraíso. Los ermitaños de Nueva España”, Historia mexicana, México, El Colegio de México, vol. 44, núm. 3 (I75), enero-marzo de 1995, pp. 355-383.

3. Juan de Grijalva, Crónica de la Orden de Nuestro Padre San Agustín en las provincias de Nueva España, Nicolás León (ed.), México, Imprenta Victoria, 1924, lib. I, cap. 3, pp. 24 y ss.

4. Recuérdese la obra de fray Matías de Escobar, Americana Tebaida, Vitas Patrum de los religiosos hermitaños de Nuestro Padre San Agustín de la Provincia de San Nicolás de Tolentino de Michoacán, México, Imprenta Victoria, I924. 
I. Demonio cargando un libro, sala de profundis, Convento de Actopan, México. Conaculta-INAH-Méx. Reproducción autorizada por el Instituto Nacional de Antropología e Historia. Foto: Desirée Moreno Silva.

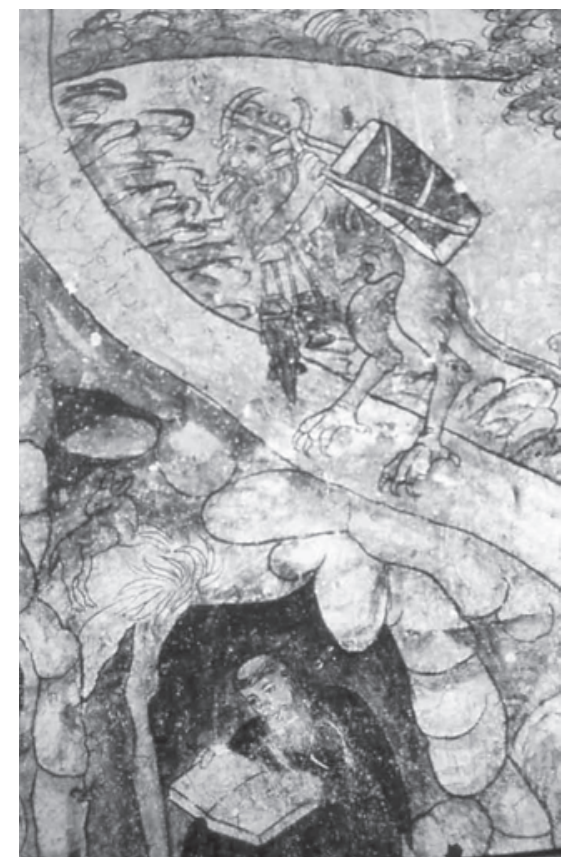

recorrieron daban pie a hablar del tema del desierto eremítico, habitado por el Demonio; la práctica de ayunos y oraciones para vencerlo permitía comparar a estos misioneros itinerantes con los anacoretas de las tebaidas primitivas. El tema era ciertamente un recurso retórico, pues para realizar sus trabajos misionales los religiosos necesitaban séquitos de cargadores, de intérpretes que les facilitaran el contacto con los pueblos aborígenes y de guías que los condujeran por los mejores caminos; el fraile real, que quería vivir temporadas en soledad, debió tener poco tiempo disponible para ello y una constante compañía. En la hagiografía de las crónicas era preciso, sin embargo, mostrar las hazañas personales de sus "padres fundadores" junto con su eremitismo individual, pues ello era prueba de la continuidad del ideario agustiniano en América. Era indispensable, además, mostrar la absoluta ortodoxia de estos misioneros, por lo que las narraciones se apegaban a los modelos sacralizados de los ermitaños antiguos como san Antonio y san Jerónimo. Esto era aún más imperioso a causa de la mala experiencia en Europa de la Congregación de San Pablo, adscrita a la Orden de San Agustín para su protección y fundada en Italia y en España por un soldado español. Dicha organización había reunido desde 1555 a numerosos individuos (algunos 
de ellos frailes y soldados prófugos) que vivían alejados del mundo y sujetos a escasos controles eclesiásticos, lo cual, unido a algunos "excesos", provocó su disolución en $1568:^{5}$ era fundamental deslindar a los frailes novohispanos de esas tendencias eremíticas poco ortodoxas.

De manera paralela a la retórica de las crónicas, podemos notar en la comunidad agustina novohispana de la segunda mitad del siglo XvI varios experimentos de vida eremítica. Para entonces, el primer ímpetu misional había pasado y la iglesia novohispana se consolidaba con el surgimiento de nuevas formas de religiosidad, lo cual provocó que las tebaidas cenobíticas dentro de los cauces institucionales encontraran una mejor acogida. Así, desde 1557, funcionaba en el Convento de Tzitzicaxtla un paraje destinado a la vida contemplativa, por lo que a esta casa se la conocía también como "la ermita" ${ }^{6}$ Fray Pedro Suárez de Escobar, electo definidor en I578, se retiró ahí como anacoreta. Años después, este mismo personaje, al que apodaban "el ermitaño" y que vivía en Ocuila, se iba largas temporadas a las cuevas de Chalma, donde se veneraba una imagen de Cristo que había sustituido al dios prehispánico de las cuevas Oxtotéotl. Este lugar era utilizado por muchos religiosos agustinos como eremitorio todavía a principios del siglo Xvir. ${ }^{7}$ A él llegó el famoso ermitaño mestizo Bartolomé de Torres, a quien el mismo fray Juan de Grijalva, entonces prior en Malinalco, le dio el hábito de la orden para que desde la cueva de Chalma se convirtiera en un emisario de la espiritualidad de esa agrupaión.

En Michoacán, recién creada la provincia de San Nicolás Tolentino en I603, se intentó fundar una casa como las de Tzitzicaxtla y Chalma. Cuenta el cronista fray Diego de Basalenque que fray Francisco de Acosta trató en I605 de crear un yermo cerca de Santiago Undameo para que los religiosos pudieran retirarse a él, pero la cercanía de Valladolid y del camino real no ofrecieron la quietud necesaria para la vida contemplativa. Por otro lado, el provincial fray Pedro de Vera no juzgó necesaria una casa de retiro, "porque en un convento, si uno quiere estarse solo en su celda, de ella hace ermita y desierto, y acude a los actos de comunidad". 8

5. Román de la Higuera, Crónica de la orden de los ermitaños del glorioso padre San Agustín, Salamanca, Casa de Joan Baptista de Terranova, I569, f. I3 Iv. y ss.

6. Grijalva, op. cit., lib. II, cap. I7, p. 293.

7. León, apéndice a Grijalva, op. cit., p. LIII, n. I2; Archivo General de la Nación, México, Ramo Congregaciones, f. i I Ir.

8. Diego de Basalenque, Historia de la provincia de san Nicolás de Tolentino de Michoacán, Gerardo Sánchez Díaz (ed.), Morelia, Balzal, 1989, lib. II, cap. 4, p. 303; Nicolás Navarrete, His- 


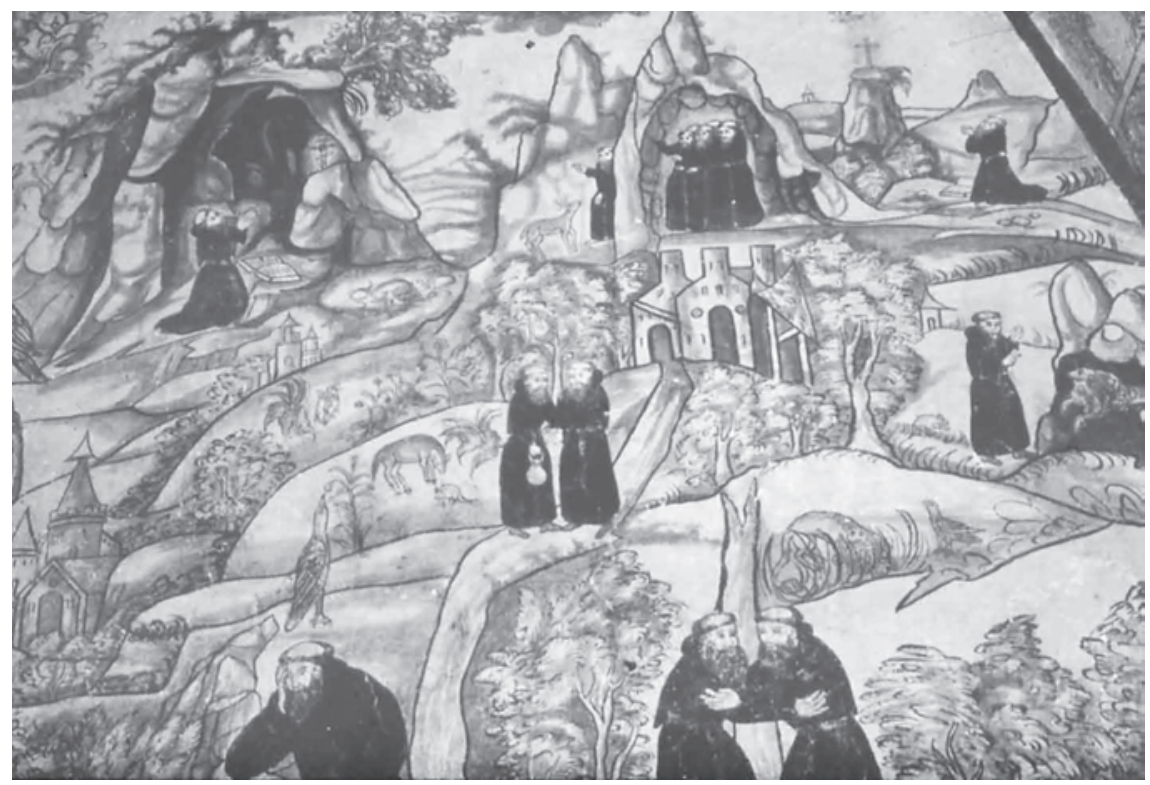

2. Los ermitaños san Antonio y san Pablo, sala de profundis, Convento de Actopan, México. Conaculta-INAH-Méx. Reproducción autorizada por el Instituto Nacional de Antropología e Historia. Foto: Antonio Rubial.

En este contexto debemos entender un fenómeno iconográfico propio de los agustinos que posiblemente formó parte del programa pictórico de todos sus conventos novohispanos a partir de 1570 . El modelo iconográfico ya había aparecido en Europa y se puede observar, por ejemplo, en un mural del Camposanto de Pisa de mediados del siglo xiv con todos los elementos propios de las tebaidas desarrollados en adelante: cuevas, demonios, animales, bosques y ermitańos solitarios o en parejas que realizan ejercicios de ascetismo, trabajo, estudio y oración. Por las mismas fechas (I354-I 409), Gerardo Starnina pintaba una célebre tebaida con ermitańos y ciervos distribuidos en un agreste paisaje montañoso, tema que se volvió muy popular en el siglo xv. ${ }^{9}$

toria de la provincia agustiniana de San Nicolás Tolentino de Michoacán, 2 vols., México, Porrúa, 1978, vol. I, pp. 303 y ss.

9. Jacques Le Goff, "El desierto y el bosque en el Occidente medieval", en Lo maravilloso y lo cotidiano en el Occidente medieval, Barcelona, Gedisa, I986, p. 39. 
En los casos novohispanos, la presencia de los murales eremíticos en los claustros es muestra de una extrańa paradoja, consecuencia de esa misma situación que exaltaba por un lado la vida solitaria y por el otro los requisitos de participar en actividades comunitarias: las representaciones de los yermos (espacios no institucionalizados abiertos a la naturaleza) se encuentran enmarcadas por recintos cerrados e institucionales.

Durante la Edad Media, el claustro representaba un jardín cerrado, paraíso terrenal que servía para la contemplación y la oración. El pozo de agua que se encontraba en el centro de ese espacio, así como las plantas del huerto monacal, simbolizaban la fuente de donde salían los ríos de la gracia y las virtudes que adornaban la vida de los monjes. En contraste, el desierto eremítico, relacionado con la naturaleza salvaje e indómita, estaba en el extremo contrario del jardín monacal y su naturaleza domesticada. Mientras éste recordaba el locus amoenus, el otro se vinculaba con las meditaciones virgilianas y melancólicas del bosque sagrado (sacro bosco) donde el hombre confrontaba en la soledad su pequeñez con la grandeza divina manifestada en la naturaleza. Por otro lado, mientras que en los huertos la mano ordenadora del hombre estaba siempre presente y los productos eran obtenidos por el trabajo, en el yermo el hombre obtenía su alimento de la providencia, de cuya mano dependía en absoluto.

Fernando de la Flor, en La península metafísica..., señala esto al respecto:

Estamos ante lo que es una sutil inversión de los principios que determinan el jardín conventual, generalmente ubicado en el claustro y al que la reforma benedictina dará el título expreso de paraíso. Se trata por el contrario, en el caso singular del que hablamos de los desiertos espirituales, de una extraversión de lo natural hacia la exterioridad, conservando en el centro un pequeño núcleo edificatorio. El jardín místico total se encuentra así rodeando el mundo del hombre, y no ya custodiado en su interior, como era lo habitual en el propio proyecto del espacio cenobítico normalizado. ${ }^{\text {Io }}$

Entre los conventos agustinos novohispanos que aún conservan algún resto de escenas de la tebaida primitiva figuran Tlayacapan, Atlatlauhcan, Meztitlán, Actopan, Zacualpan, Culhuacán, Charo, Tezontepec, Totolapan, Huatlatlauca, Acolman y Malinalco. Sin embargo, es casi seguro que éste era un tema que debió representarse en todos los conventos novohispanos de la orden.

Io. Fernando de la Flor, La peninsula metafisica. Arte, literatura y pensamiento en la España de la Contrarreforma, Madrid, Biblioteca Nueva, I999, p. I32. 


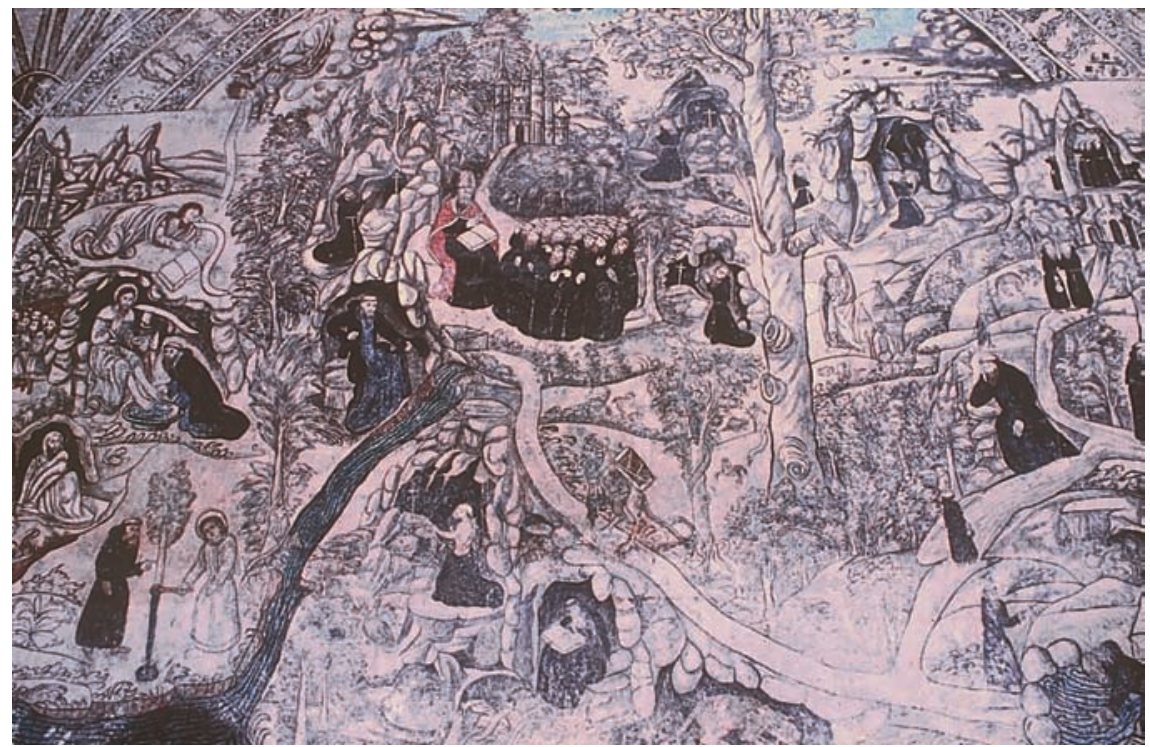

3. Escena de la vida de san Agustín, sala de profundis, Convento de Actopan, México. Conaculta-INAH-Méx. Reproducción autorizada por el Instituto Nacional de Antropología e Historia. Foto: Archivo Fotográfico IIE-UnAM.

De acuerdo con lo que conocemos de dichas escenas, podemos señalar dos tipos de ellas: uno que tiene como centro un Cristo crucificado al que se dirigen devotos dos o más frailes ermitaños y otro donde se representa un espacio abierto donde aparecen pequeñas figuras vestidas con hábitos negros y enmarcadas por un paisaje con rocas, árboles y animales.

Respecto al primer tipo podríamos considerar como la escena más representativa la que se encuentra en el testero del refectorio del Convento de San Juan Bautista de Tlayacapan (Morelos), conjunto iniciado en 1566 y que debió decorarse entre 1575 y 1580 . Ahí, a ambos lados de un gran Cristo crucificado, están pintados dos enormes ermitańos arrodillados, con aureola y en actitud de rezar, en medio de un bosque de frondosos árboles. Varias aves paradas sobre sus copas y un conejo o liebre muestran la simbología tradicional de la lucha entre vicios y virtudes.

En el vecino Convento de la Concepción, en Atlatlauhcan, construido posteriormente al de Tlayacapan y decorado posiblemente a finales de la década de 1580-1590, aparece de nuevo el tema, pero ahora en otro espacio, que debió 
ser parte de la "sala de profundis". El mural, recientemente descubierto y muy maltratado, tiene en su centro de nuevo un gran Cristo en la cruz con una Jerusalén al fondo que recuerda la construcción del mismo conjunto conventual. Dos figuras lo flanquean: a la izquierda, al lado de una gran roca, parece haber un personaje que lleva un hábito blanco y un manto negro en la forma como a menudo se representa a san Antonio Abad; a la derecha, otra figura, mejor conservada, es la de un san Jerónimo arrodillado, que golpea su pecho con una piedra y con un pequeño león emblemático enfrente. Detrás de él, su capelo cardenalicio (otro de sus atributos) cuelga del tronco de un gran árbol, a los pies del cual se adivina a un pequeńo fraile dormido, muy deteriorado, que puede aludir al sueño de san Agustín.

Un tercer ejemplo de esta tipología se puede observar en el refectorio del Convento de los Santos Reyes en Meztitlán. En él, seis frailes agustinos, descalzos, con sus cabezas tonsuradas y sus hábitos negros, se distribuyen alrededor de un Cristo crucificado, y rezan, se flagelan o leen. El paisaje que los rodea, formado por arbustos, yerbas, nopales y grandes árboles, recuerda el yermo eremítico. Sin embargo, entre el follaje se pueden distinguir algunas construcciones que recuerdan los templos fundados por los agustinos en la vega de Meztitlán. Vistos como ermitas, estos núcleos arquitectónicos refuerzan la idea de que, a pesar de su labor evangelizadora, los ermitaños de San Agustín han transformado su espacio de misión en una tebaida. Entre los arbustos, aún se pueden apreciar dos animalillos, un conejo y un ciervo, que como hemos visto tienen fuertes cargas simbólicas para el contexto eremítico. En la parte alta, un sol y una luna con rostro humano hacen referencia al paraíso, lugar donde no había noche y en el que ambos astros brillaban simultáneamente. ${ }^{\text {II }}$

La segunda tipología de las tebaidas novohispanas, en la que se representan espacios abiertos, fue al parecer la más socorrida. En ella aparece generalmente un paisaje desértico con escasa vegetación que representa la vida de austeridad y abandono de los placeres de los sentidos. A menudo en ese paisaje están representados los animales emblemáticos de la vida eremítica: el león, símbolo paradigmático de la fortaleza espiritual de los ermitańos; el ciervo, cuya habilidad para cazar serpientes en sus cuevas lo asocia con quienes luchan contra

I I. El mural ha sido estudiado por Martín Olmedo Muñoz, "Las pinturas murales del siglo XVI en el convento agustino de Meztitlán, Hidalgo: el programa iconográfico, sus posibles modelos e implicaciones teológicas", tesis de maestría, México, Universidad Nacional Autónoma de MéxicoFacultad de Filosofía y Letras-División de Estudios de Posgrado, 2007. 
4. La muerte y el fraile, interior del confesionario en el claustro bajo del Convento de Malinalco, México. Conaculta-InaH-Méx. Reproducción autorizada por el Instituto Nacional de Antropología e Historia. Foto: Ricardo Alvarado. Archivo Fotográfico IIE-UNAM.

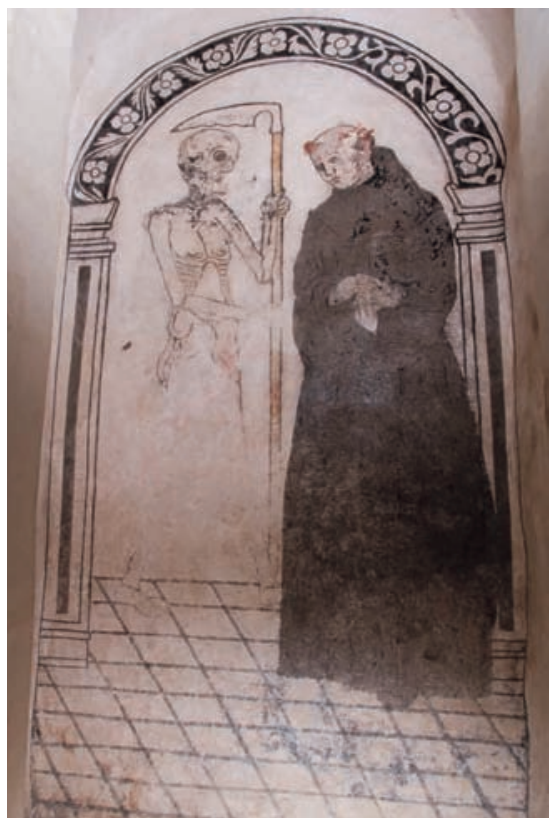

el Demonio y lo vencen; el ave que ataca a un conejo, emblema que habla de la castidad triunfante sobre la lujuria, psicomaquia con larga tradición en el cristianismo, y la serpiente, que hipnotiza a un pajarillo o a un roedor y representa la tentación demoniaca. Ahí también debieron aparecer las diferentes labores de los frailes eremitas: la oración, actividad fundamental de la vida del religioso; la lectura de la Biblia, cuyo estudio exhaustivo formaba parte esencial de la espiritualidad de san Agustín; el trabajo manual, principal antídoto contra la acidia y recurso para no caer en tentación; la conversación espiritual esporádica como un medio de acercarse a Dios a través del prójimo, y la flagelación como instrumento para someter el cuerpo a los dictados del espíritu.

Uno de los murales mejor conservados sobre este tema se encuentra en la "sala de profundis" del Convento de San Nicolás Actopan, donde aparecen varios de los más importantes tópicos eremíticos, descritos en pasajes de la vida del santo fundador, que se equiparan con las de los ermitańos egipcios san Pablo y san Antonio. En la parte baja, una cartela semiborrada reza: [...] Eremite [...] Cenobio [...] ntanachoritecu [...] Agustin lumen misceritas Antonio (Eremitas [...] cenobitas [...] anacoretas [...] Agustín comparte la iluminación de Anto- 
nio). La frase hace alusión a un pasaje de las Confesiones donde se describe cómo el relato de Ponticiano sobre san Antonio fue determinante en su conversión.

Una gran higuera o peral parte la escena en dos para separar los espacios hagiográficos por comparar. En la sección de la mano izquierda están representadas escenas de la vida de san Agustín, quien aparece en varias de ellas como ermitaño. Para el propósito de este ensayo, no me interesa abundar sobre algunas, como la de su conversión, su bautismo o sus visiones de Jesús, y sólo me referiré a otras en que lee y ora dentro de una cueva. A ese conjunto están vinculados dos temas sobre la tentación: el Demonio, figura que en Actopan tiene los rasgos de un tameme con cara humana, lengua bífida, cuerpo leonino, patas con garras de águila y cola de serpiente, y que lleva sobre sus espaldas un libro sostenido por cuerdas que penden de sus cuernos, además de un tintero y un portaplumas atados a su cuello, atributos vinculados con su actividad de recopilador de los pecados de los hombres. Junto a él, en un pequeño árbol, se enrosca una serpiente, recuerdo del jardín del Edén. La escena ilustra el pasaje de la vida de san Agustín donde el diablo se le presentó durante su retiro. ${ }^{\mathrm{I2}} \mathrm{Al}$ igual que en todos los paraísos eremíticos, en éste el nuevo Adán era también tentado, aunque vencía al tentador, con lo que se revertía lo que había sucedido en el Edén.

Frente al tema paradisiaco negativo de la tentación estaba también el positivo, el dominio de Adán sobre los animales. De ahí que, sobre el lado izquierdo del mural, san Pablo y san Antonio aparezcan representados en un paisaje lleno de árboles y animales como ciervos, conejos, lobos, aves y leones. ${ }^{13}$ En el lado este del mural, en medio de una naturaleza agreste, aunque marcada por caminos trazados por el hombre, aparecen representados todos los elementos propios de las tebaidas tradicionales: las cuevas, la oración, el estudio, el ascetismo y el dominio sobre los animales. Gracias a este don, los ermitańos restituían a la naturaleza su armonía primigenia, representada por la convivencia con esos seres salvajes. Sin embargo, la gran ausente en esos paraísos eremíticos era Eva; los Adanes del desierto tenían incluso como orgullo resistirse a toda presencia

I2. Desirée Moreno Silva, "La tebaida del convento agustino de San Nicolás Actopan. Estudio formal, iconográfico e iconológico de una pintura del siglo Xvı", tesis de licenciatura, México, Universidad Nacional Autónoma de México-Facultad de Filosofía y Letras, 2002.

13. El tema del encuentro entre san Pablo y san Antonio se inspira en la vida del primero, que escribió san Jerónimo. En la Edad Media la escena se representó abundantemente, como en el cuadro de Stephano di Giovanni (Sassatta), Encuentro entre san Antonio y san Pablo, de la National Gallery of Art de Washington. 


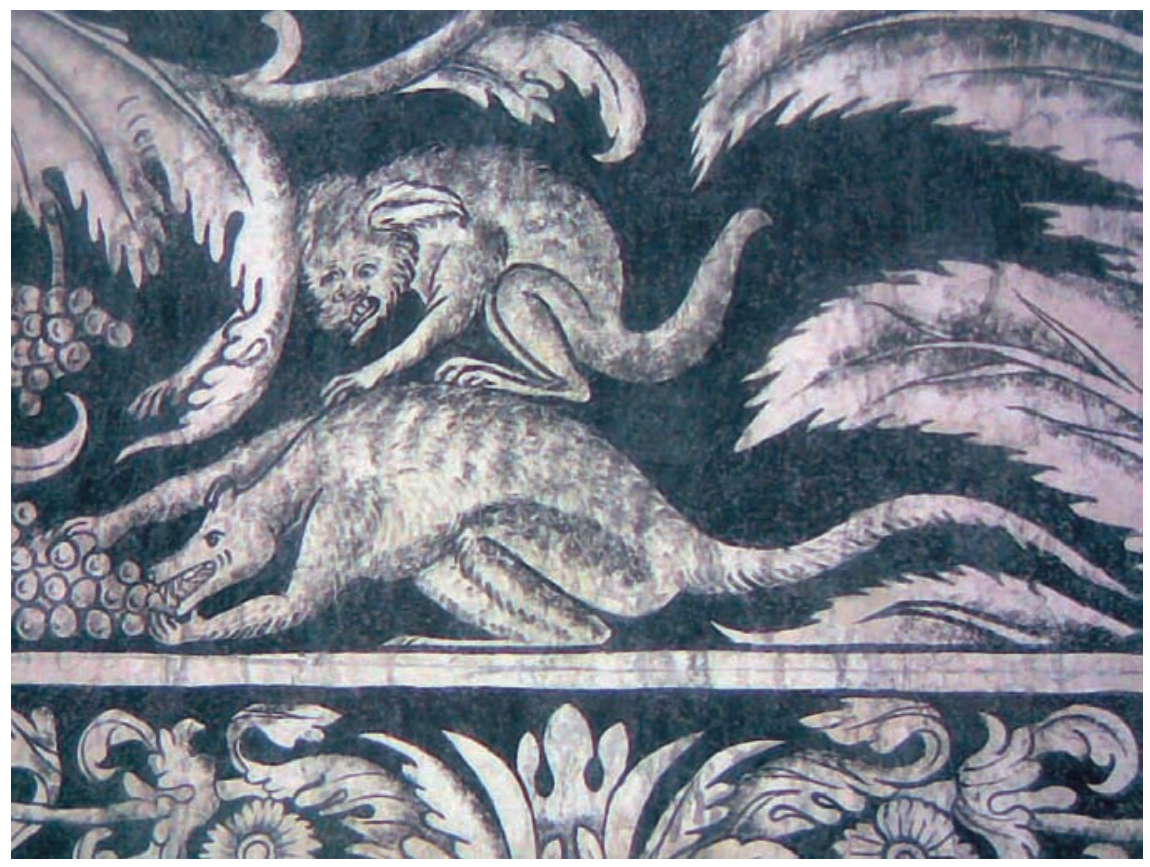

5. Felino y tlacuache, claustro bajo del Convento de Malinalco, México. Conaculta-INAH-Méx. Reproducción autorizada por el Instituto Nacional de Antropología e Historia. Foto: Malke Corenstein.

femenina, evitando así la tentación con el rechazo, como principio de la causante de la caída y de la pérdida del paraíso.

El mural fue pintado posiblemente para el capítulo de Actopan de I58I, al cual asistió Pedro Suárez de Escobar, fraile renombrado, como vimos, por sus ideales eremíticos. Parece lógico pensar que en los momentos en que se construía la idea de una Edad Dorada, el tema de las tebaidas asociadas con la vida de san Agustín como eremita se considerara el más apropiado para una sala donde los frailes se reunirían con el fin de decidir los destinos de la provincia.

Otra tebaida agustina conservada casi intacta se encuentra en la sala de profundis del Convento de la Concepción, en Zacualpan de Amilpas. En ella se ha eliminado el tema de la vida de san Agustín, pero se conservan los diferentes espacios y convenciones tradicionalmente asociadas con el yermo pintadas sobre un fondo ocre en un paisaje de riscos y pinos. Un demonio con rasgos animalescos, como un perro alado con cuernos, acecha desde la parte baja del mural 


\section{ANTONIO RUBIAL GARCÍA}

las diferentes actividades de los ermitaños. Éstos leen, cargan leña, caminan, se flagelan, oran y labran la tierra. Algunos están solos, otros se hallan con un compañero. La presencia y variedad de animales es notablemente menor que en la tebaida de Actopan. Dos leones, un ocelote, un lobo [i? ${ }^{2}$ y una serpiente que se aproxima sigilosa a una comadreja son los únicos seres que comparten el espacio con los ermitaños. Sobre el lado izquierdo y en primer plano sobresale una figura emblemática del eremitismo: san Jerónimo, con aureola, desnudo y de rodillas frente a una calavera, planta su pie sobre un enorme león, mientras una reptante serpiente pasa a su lado. ${ }^{14}$ No tenemos ningún referente de la fecha de elaboración del mural, pero sin duda es posterior a 1570 .

La tercera tebaida que se mantiene en bastante buen estado se localiza en el claustro del Convento de San Juan Evangelista en Culhuacán, distribuida en tres de las cuatro esquinas del edificio. En este interesante mural, el color que domina es el azul. La primera parte de la pintura se encuentra a la entrada del claustro, arriba y a los lados de la puerta que da acceso a la anteportería. En esa sección, una palmera resalta en medio del yermo, pero en el resto del paisaje, al igual que en las otras tebaidas analizadas, la vegetación resulta escasa. Un gran león como gato dibujado en líneas negras, un ocelote que gira su cabeza ciento ochenta grados y un ave que ataca a un conejo cuya factura se aleja de los modelos europeos son los animales que aparecen en estas escenas. Varios de los eremitas, como en las otras tebaidas, se encuentran dispersos en el paisaje, arrodillados y con las manos juntas en oración. En una segunda sección muy deteriorada (en la esquina nororiental) se puede apreciar a un fraile que labra la tierra con una azada, rodeado por un bosque de pinos. En la tercera sección, a la salida del claustro hacia el cubo de la escalera, un calvario domina la escena encima de la puerta; hacia él se dirigen varios frailes vestidos de negro. A la derecha, rodeando una gran cueva, en medio de algunos árboles de cuerpo frondoso y junto a un ciervo negro, los frailes ermitaños están representados solos o en parejas; algunos conversan, otros leen libros y otros más trabajan la tierra. ${ }^{15} \mathrm{El}$ tema también debió extenderse al claustro alto, pues en el arco de una ventana se puede ver aún a dos frailes, uno en actitud de rezar y otro con un libro, que dirigen su mirada hacia un lejano

I4. En la biografía de san Jerónimo se narra cómo obtuvo éste la amistad de un león al quitarle una espina de la pata. Louis Reau, Iconografía del arte cristiano, 5 vols., Daniel Alcoba (trad.), Barcelona, Ediciones del Serbal, I996, vol. 4, p. I44.

I5. Gabriela Martínez Ulloa Torres, "A la orilla de la laguna. La pintura mural del convento de Culhuacán”, tesis de maestría, México, Universidad Nacional Autónoma de México-Facultad de Filosofía y Letras-División de Estudios de Posgrado, 2003. 
6. Ciervo, serpiente y ave, claustro bajo del Convento de Malinalco, México. ConacultaINAH-Méx. Reproducción autorizada por el Instituto Nacional de Antropología e Historia. Foto: Malke Corenstein.

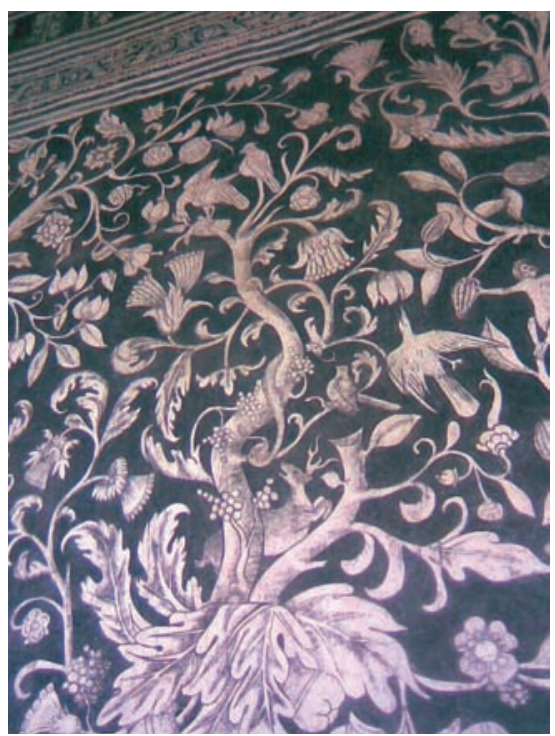

calvario. Los murales debieron de pintarse también después de 1580 , pues en I576 los habitantes del pueblo se habían comprometido a proporcionar la cal necesaria para la campaña constructiva. ${ }^{16}$

En el Convento de San Miguel, en Charo, quedan restos del programa mural de la tebaida que debió ser pintada en la época de fray Pedro de San Jerónimo, quien se encargó de trasladar la iglesia al lugar que ahora ocupa y encabezó la construcción del claustro bajo y su decoración entre 1570 y I576. ${ }^{17}$ El mural es descrito por el cronista Matías de Escobar, según el cual el prior fray Pedro de San Jerónimo mandó pintar "Una montaña a la moda de Tagaste y con gran semejanza a las de Egipto en la Tebaida, como diciendo lo que pensaba y guardaba en su corazón: martirios y soledades". ${ }^{18}$ Muy posiblemente el mural de Charo repetía los mismos tópicos de las otras tebaidas.

En Tezontepec, en el Convento de San Pedro, cuya construcción se inició en $\mathrm{I} 57 \mathrm{I},{ }^{19}$ la tebaida se encuentra representada en un deteriorado mural del

I6. George Kubler, Arquitectura mexicana del siglo XVI, México, Fondo de Cultura Económica, I982, p. 6I 4 .

17. Basalenque nos informa que fray Pedro de San Jerónimo fue prior del convento hasta su muerte en I576. Basalenque, op. cit., lib. I, cap. XV, pp. I66 y ss.

I8. De Escobar, op.cit., p. 794.

19. Kubler, op. cit., p. 623. 
cubo de la escalera. Toda la parte baja de la pintura muestra un mundo acuático lleno de peces y ondas azules. Sobre el muro que está subiendo la escalera a mano derecha, aves, mariposas y libélulas (las virtudes) vuelan sobre un paisaje de árboles y montañas. En esta parte, y también sobre el muro izquierdo en un tamaño mayor, se puede observar la representación de una montaña con puntos negros, que posiblemente alude a la grava relacionada con la toponimia del lugar: cerro de tezontle. ${ }^{20}$

En el muro central un nicho conopial enmarcado por una cenefa podría ser la cueva eremítica; aunque la pintura interior ha desaparecido, podemos aventurar la hipótesis de que ahí había posiblemente un ermitaño pintado con una calavera y en actitud de orar. Esta hipótesis se refuerza por la imagen casi borrada de un ciervo que se encuentra cerca del nicho, cuyas asociaciones con la vida del yermo ya se han mencionado. ${ }^{2 \mathrm{I}}$

También en el cubo de la escalera del Convento de San Guillermo Totolapan, se conservan restos de lo que debió ser una tebaida. En la parte alta de uno de los lunetos se puede ver aún un conejo que sale de una cueva, mientras una serpiente que va a atacarlo es atrapada por un águila. No queda ningún otro elemento, ni frailes ni bosques, pero muy posiblemente en el resto del cubo debió haber tales alusiones que hemos podido constatar en las otras casas agustinas.

En el claustro alto del Convento de Santa María de los Reyes, en Huatlatlauca (pueblo que los agustinos tomaron bajo su cargo en 1566), el mural que representa la tebaida, aunque también muy deteriorado, nos permite vislumbrar un paisaje azul verdoso sobre el que están representados varios frailes con hábito negro. Sobre el lado izquierdo, sus figuras están más esparcidas en el espacio y entre ellas hay algunas manchas de color ocre que podrían haber sido imágenes de animales. Del lado derecho, en mejor estado de conservación, los frailes forman un grupo compacto, están sentados o de rodillas, algunos con sus manos sobre el pecho, y atentos a la alocución de un religioso agustino de gran talla cercano a una enorme roca negra. El predicador, con las manos levantadas a la altura del pecho, podría estar hablando de la excelsitud de la vida eremítica representada a las espaldas de su auditorio. El lugar donde se encuentra esta pintura también es muy significativo, pues frente a ella se despliega el famoso mural de la danza macabra. Ahí, un grupo de personas de diferentes estamentos (papas, cardenales, obispos, frailes y laicos nobles, hombres y mujeres, españoles

20. Agradezco a Pablo Escalante esta observación.

2I. Agradezco a Martín Olmedo haberme facilitado fotografías de este mural. 


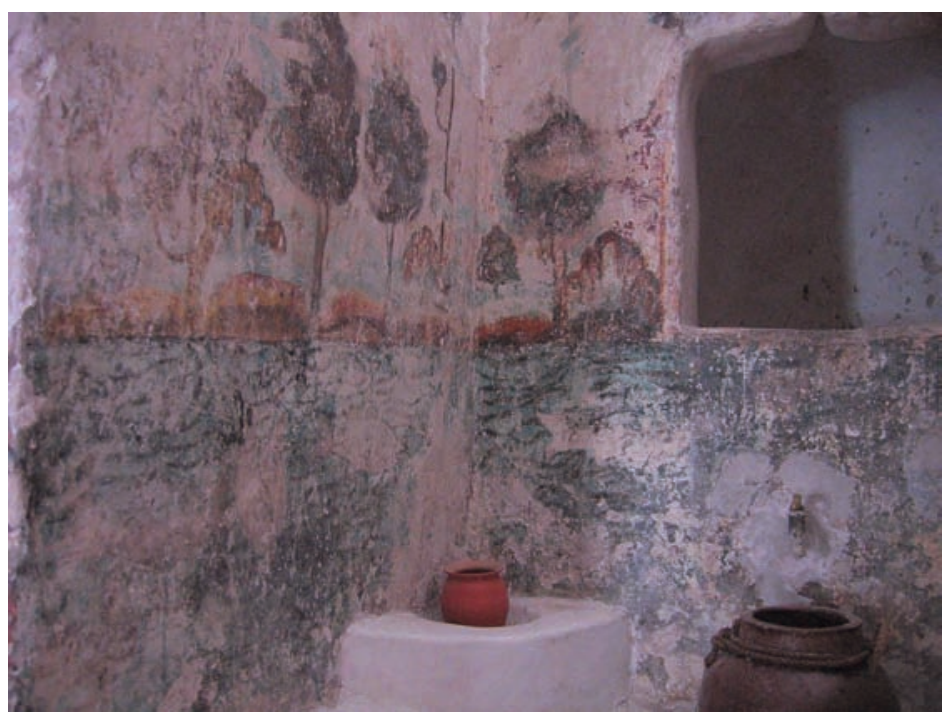

7. Paisaje con animales, cubo de la escalera, Convento de Tezontepec, México. Conaculta-INAH-Méx. Reproducción autorizada por el Instituto Nacional de Antropología e Historia. Foto: Martín Olmedo.

e indígenas) es atacado por un enorme esqueleto armado con arco y flechas. La meditación sobre la muerte, uno de los temas de la vida eremítica, parece tener su razón de ser a partir de la tebaida representada enfrente. ${ }^{22}$

Algunas escenas que nos recuerdan el tema se encuentran también en el muro oriental del claustro bajo del Convento de San Agustín Acolman. Ahí sólo se conserva la parte alta del mural, la más cercana al techo. Sobre la mano derecha se puede ver aún a un pequeño fraile que observa una cruz en las rocas, arrodillado en medio de un paisaje montañoso y bajo un retorcido árbol. En la siguiente escena, hacia la izquierda, una mujer es elevada al cielo por cuatro ángeles, tema que nos remite a la vida de la santa ermitańa María Magdalena, junto a los tres cuervos que la rodean. Finalmente, sobre la mano izquierda, de nuevo entre árboles y montańas, está representada una capilla sobre la cual

22. Sobre este mural se puede consultar el artículo de Hortensia Rosquillas, "La danza de la muerte en una pintura del convento de Huatlatlauca, Puebla”, Boletín de Monumentos Históricos, México, Instituto Nacional de Antropología e Historia, núm. 6, enero-abril de 2006, pp. I2-24. Agradezco a la autora su amabilidad al facilitarme los datos contenidos en la descripción de la tebaida de este convento. 
se posa un personaje que señala un nido en lo alto de una roca. Del nido sale una serpiente y sobre él vuela un águila, temas de nuevo asociados con la tentación y posiblemente con las vidas de san Honorato de Arlés o de san Bavón de Gante, ermitaños que lucharon contra el Demonio y la herejía. ${ }^{23}$ Diversas aves sobrevuelan el paisaje como en las demás tebaidas. Parece que la escena fue pintada sobre otra anterior de la que se puede observar un frontón y una columna-candelabro. Sabemos que alrededor de 1580 el convento albergaba a una veintena de estudiantes y quizá la pintura se remita a ese periodo en que había en él un estudio.

Algunas de las características de estas tebaidas murales también las encontramos en el programa mural del claustro conventual de Malinalco, pintado posiblemente también alrededor de 1580 , puesto que el convento apenas se hallaba en construcción en I57I. ${ }^{24}$ Algunos autores, como Elena Estrada de Gerlero y Jeannette Favrot, han considerado este mural la representación de un paraíso con plantas y animales nativos y lo han relacionado con la llegada del médico de Felipe II Francisco Hernández, quien solicitó a un grupo de tlacuilos para llevarse referencias pictóricas de las plantas medicinales que recopilaba. Varias escenas de violencia entre los animales concentradas en el muro oriente podrían aludir, según esa interpretación, a un edén ya corrompido por el pecado. ${ }^{25} \operatorname{Sin}$ embargo, como hemos visto en otras tebaidas agustinas, los animales en lucha representan virtudes y vicios y las tentaciones a las que se enfrenta el ermitaño.

A partir de la idea de que en Malinalco está representada una tebaida, la lectura puede comenzar en el muro sur, donde los grandes anagramas de Cristo y María están rodeados únicamente de vegetación con flores (de virtud) y de aves, seres asociados con las almas virtuosas. En el muro oriente, en cambio, se concentran árboles frutales y animales en pugna: un ciervo que va a atacar a una serpiente, típica alusión —como hemos visto-a la vida eremítica, un águila que devora a un pajarillo y una especie de tejón o tlacuache atacado por

23. San Bavón de Gante tiene como atributos un halcón y una espada, y fue un noble belga seglar la mayor parte de su vida, hasta que eligió ser ermitańo. San Honorato de Arlés, otro noble ermitańo, fue transportado por los herejes a la isla de Lérins, donde venció a dos monstruosas serpientes con una señal de la cruz. Reau, op. cit., vol. III, pp. I 88 y ss.; vol. IV, pp. 88 y ss.

24. Kubler, op. cit., p. 6I8.

25. Elena Isabel Estrada de Gerlero, "Malinalco. Orígenes de su traza, convento y capillas", en Malinalco, imágenes de un destino, México, Banca Cremi, I989. Jeannette Favrot Peterson, The Paradise Garden Murals of Malinalco: Utopia and Empire in Sixteenth-century Mexico, Austin, University of Texas, 1993. 
8. San Jerónimo con un león, sala de profundis del Convento de Zacualpan de Amilpas, México. Conaculta-INAH-Méx. Reproducción autorizada por el Instituto Nacional de Antropología e Historia. Foto: Antonio Rubial.

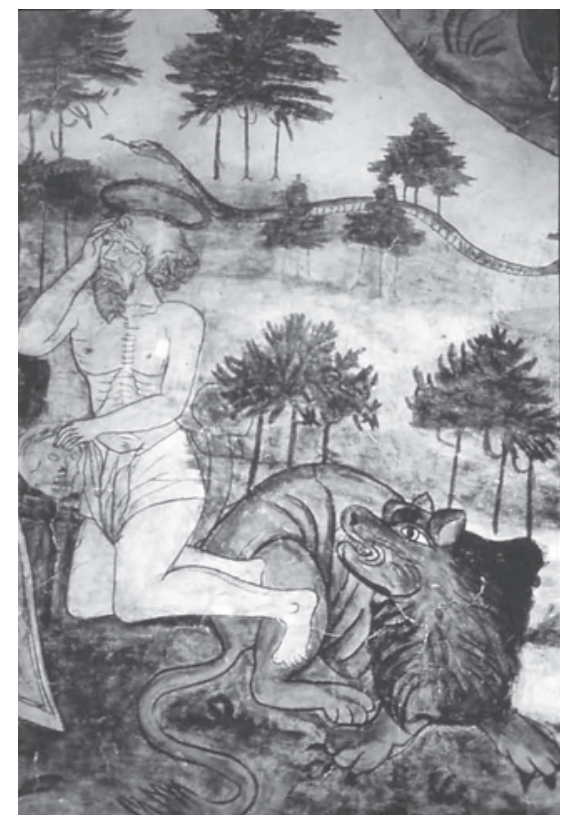

un felino mientras consume frutas. Otros animales también están representados acá cuando comen: un tipo de ardilla devora una granada y un mono agarra una fruta que parece cacao. Este animal, vinculado con la lujuria, y otros mamíferos que gozan de comida (la gula) inducen a pensar en un mensaje relacionado con los vicios y las tentaciones. Aunque en este espacio no aparece el Demonio directamente figurado, la serpiente tiene en él un papel muy importante. Considero central la escena en que una serpiente encanta a un pajarillo mientras el ciervo se dispone a atacarla por la cola, clara referencia oblicua a la tentación vencida por medio de la gracia. La hipótesis de que en Malinalco se representa un hortus eremitarum se ve confirmada con las pinturas del muro norte, cuyo centro es la cavidad del confesionario. Dentro de ella se ha figurado a un monje de pie frente a un esqueleto (que recuerda el de Huatlatlauca, aunque sin armas), escena que cumple la función característica de las tebaidas: el ermitaño en su cueva medita sobre la muerte frente a un cráneo descarnado. La vegetación que rodea este espacio de nuevo se halla habitada sólo por aves, lo que nos habla otra vez de la virtud incontaminada por el pecado y del triunfo sobre las tentaciones. Esta interpretación del claustro de Malinalco como espacio eremítico no se contrapone a la que lo ha visto como un paraíso, pues — como hemos 


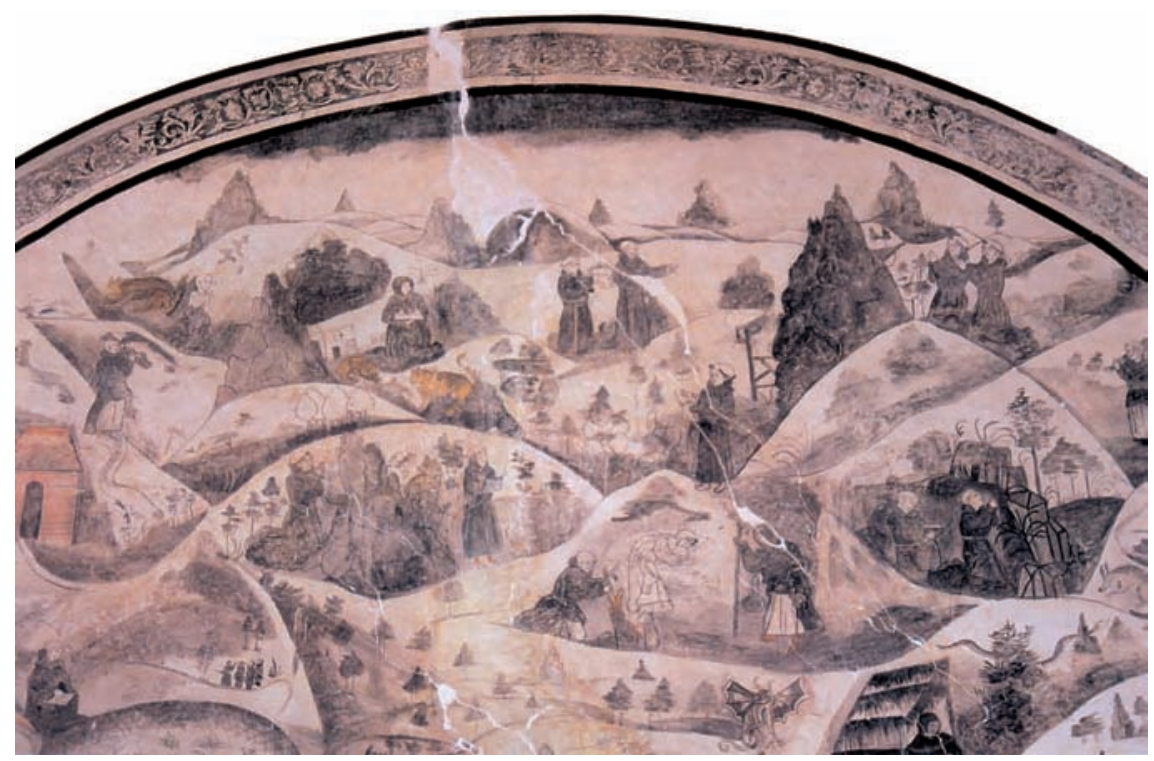

9. Tebaida, vista general, sala de profundis del Convento de Zacualpan de Amilpas, México. Conaculta-INAH-Méx. Reproducción autorizada por el Instituto Nacional de Antropología e Historia. Foto: Antonio Rubial.

señalado- el hortus eremitarum tiene también el sentido del paraíso terrenal que ha sido restituido por la gracia.

En las tebaidas americanas agustinas no parece haber contradicción entre la vida activa de la evangelización y la vida contemplativa de los solitarios. El trabajo de los frailes en América se consideraba parte de la tarea de recuperar el paraíso perdido, edén habitado por frailes y por indios, y según tal concepción los religiosos fundaron sus pueblos. En Actopan, la asociación es clara, pues en el mural de la tebaida se han dibujado los riscos llamados de los frailes, paisaje que describe uno de los horizontes del poblado y que movía a asociar el paraíso eremítico pintado en el mural y el espacio geográfico del pueblo donde se pintó. Lo mismo pasaba en Culhuacán, donde la tebaida se representó a la orilla de un lago, como el mismo pueblo. En Meztitlán, la vega y las construcciones agustinas formaron parte del paisaje eremítico pintado en el refectorio. En Malinalco, la flora y la fauna del entorno plasmada en sus muros daban al visitante la referencia de que en ese pueblo se encontraba el paraíso donde convivían armónicamente los religiosos "ermitaños" con sus fieles discípulos 


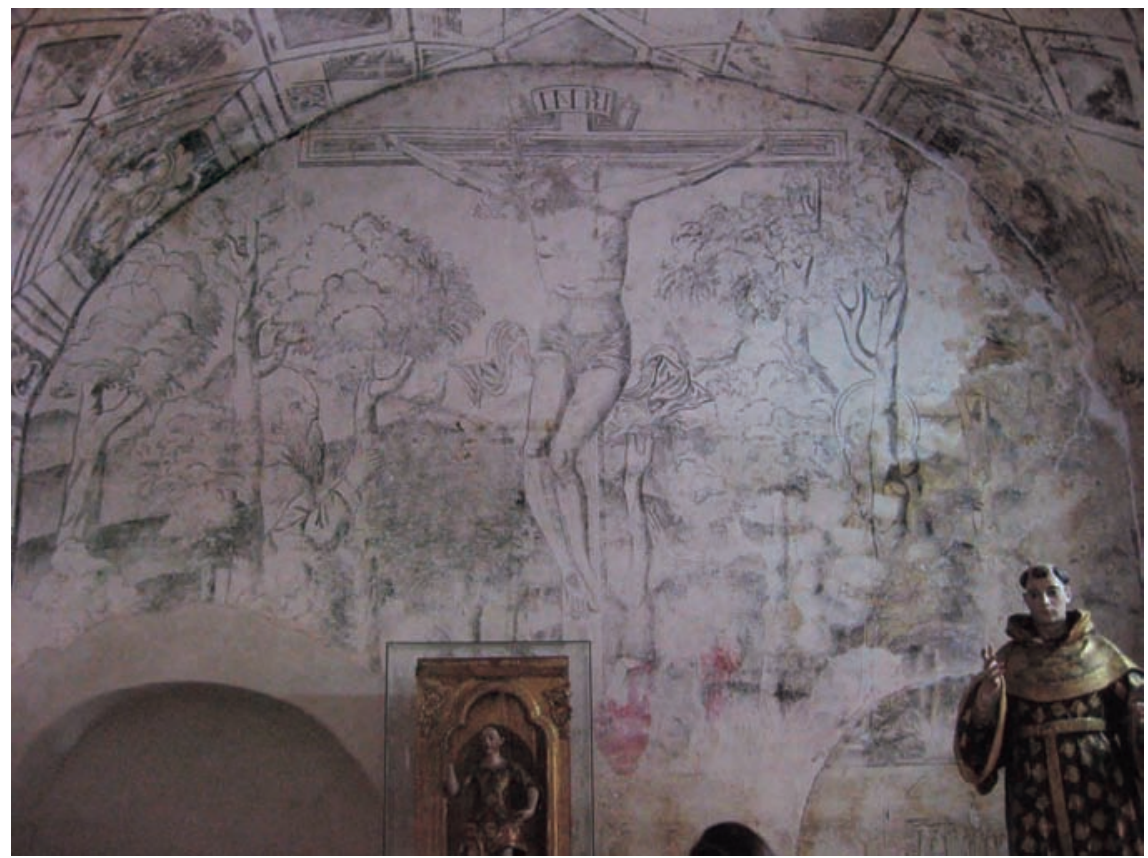

Io. Mural del refectorio del Convento de Tlayacapan, México. Conaculta-INAH-Méx. Reproducción autorizada por el Instituto Nacional de Antropología e Historia. Foto: Martín Olmedo.

indígenas. En el ámbito de lo simbólico se reconciliaban las paradojas y los solitarios podían compartir sus espacios no sólo con los animales, sino también con los habitantes de los pueblos donde estaban enclavados sus monasterios.

Es también muy significativo que las pinturas de estas tebaidas se encuentren en espacios destinados a la meditación de los frailes: los claustros bajo y alto de los conventos, la sala de profundis, el refectorio y el cubo de la escalera. Tales espacios nos permiten pensar en una exaltación de la vida contemplativa (oración, flagelación, lectura) representada por los eremitas, en claro contraste con la vida activa y de predicación asociada a la portería, la capilla abierta y la nave de la iglesia. Los mensajes de esas tebaidas tenían como fin recordar a los religiosos que habitaban el convento el espíritu original de la orden, tema que a menudo podía olvidarse en medio de las ocupaciones pastorales.

Uno de los aspectos más notables que se aprecian al comparar estos murales es su diversidad, pues aunque hay en todos ellos elementos constantes (animales, plantas, riscos y frailes), no existe un modelo a seguir ni su esquema compositivo 
parece responder a ningún grabado. Posiblemente porque no había un modelo iconográfico único, los pintores indígenas de las tebaidas agustinas pudieron recurrir a elementos autóctonos para representar animales y plantas y los frailes que las idearon pudieron expresarse con mayor libertad de la que tenían al representar otras temáticas como las pasionarias o las marianas. En cambio, una constante en estas pinturas de tebaidas es la presencia de símbolos cristológicos: crucifijos o medallones con el anagrama de Jesús ( JHS) como centro de la vida espiritual del ermitaño.

Alrededor de 1580, cuando se pintaban estos murales, Nueva España vivía una era de profundos cambios. Durante ella, las fuerzas económicas que habían controlado a los indios durante las primeras tres décadas de la colonización española (encomenderos, frailes y nobleza indígena) comenzaban a ser desplazadas por los nuevos grupos protegidos por la política filipina: la burocracia formada por alcaldes mayores y corregidores, los mercaderes y hacendados y un combativo episcopado que basaba su fuerza en el clero secular. Frente a una política tributaria más opresiva, a un mayor aumento de los intereses comerciales y a una explotación económica inhumana, avanzaba a grandes pasos la mortandad de la población indígena debilitada por las enfermedades, por el hambre y por los trabajos excesivos. Además, esa población supuestamente cristiana persistía en sus idolatrías incitada por los hechiceros, continuadores de los ritos antiguos.

Tales cambios afectaron también a las órdenes religiosas. El estancamiento de la labor misionera en el área de Mesoamérica, ya cristianizada para entonces, y las pocas perspectivas que había en el norte, asolado por la guerra chichimeca, obligaban a buscar un nuevo sentido religioso. Por otro lado, los conflictos surgidos con los obispos en aras del control de las parroquias indígenas ponían en duda la verdadera vocación que debían tener los mendicantes. Finalmente, la entrada masiva de elementos criollos a las órdenes había debilitado el cumplimiento de los principios con que habían nacido esos institutos. Los acelerados cambios sociales y económicos que vivía la Nueva España y la situación por la que pasaban las órdenes mendicantes crearon las condiciones propicias para que naciera la idea de una edad dorada situada presumiblemente en la etapa inmediata anterior.

El tema de las tebaidas agustinas estaba enmarcado por la construcción de esa Edad Dorada que se remitía a los primeros cuarenta ańos de la evangelización, etapa en que los religiosos vivieron como en los tiempos apostólicos, consagrados a la predicación y el eremitismo. Si consideramos que las pinturas murales son discursos corporativos, tanto para consolidar la cohesión interna 
entre los miembros de la orden como frente a los demás, podemos asegurar que el eremitismo se presentó como el ideario distintivo de la orden, antídoto contra el debilitamiento de la observancia y presencia idealizada ante indios y españoles que visitaban el convento. Ante la desilusión causada por una cristiandad indígena contaminada de idolatrías y frente a los ataques de los obispos, los agustinos encontraron en el tema de las tebaidas lo que para los franciscanos sería la pobreza y para los dominicos la predicación: un modo simbólico de hacer frente a una sociedad cambiante. के 